\title{
Is resistance to $P$. falciparum infection in sickle cell trait (AS) individuals is related to presence of high frequencies of haptoglobin Hp2-1?
}

\author{
Atif.A.Elagib ${ }^{1^{\star}}$, Hiba. A. Mirgani ${ }^{2}$, Nahla M. Shamsaldien ${ }^{3}$, Fatihia M. Khir ${ }^{2}$, Bakheeta, $\mathbf{M}^{4}$ \\ and Mustafa. I.Elbashir ${ }^{2}$ \\ ${ }^{1}$ Tropical Medicine Research Institute. National Center for Research-Sudan \\ 2 Biochemistry Department, Faculty of Medicine, University of Khartoum-Sudan \\ ${ }^{3}$ Genetic engineering commission, National Center for Research Sudan \\ ${ }^{4}$ Khartoum Children Hospital
}

\begin{abstract}
Sickle cell anemia is a haemoglobinpathy due to a single point mutation in the $\beta$-chain of human haemoglobin. A hospital based case control study was done on the paediatric section in Khartoum Teaching hospital to investigate the role of haptoglobin phenotypes among sickle cell disease patients. A total number of 127 sickle disease patients and 34 healthy controls were screened for $\mathrm{Hb}$ phenotypes. Out of 88 homozygous sickle cell anaemia patients (HbSS), $77.3 \%$ patients had the $\mathrm{Hp} \mathrm{1-1}$ phenotype, $22.7 \%$ had the $\mathrm{Hp} 2-1$ phenotype, and none of them had $\mathrm{Hp} \mathrm{2-2} \mathrm{type.} \mathrm{Out}$ of the 39 sickle cell trait (HbAS) individuals, $41 \%$ individuals had $\mathrm{Hp} 1-1$ phenotype, $59 \%$ had $\mathrm{Hp} 2-$ 1 phenotype and none of them had the $\mathrm{Hp} \mathrm{2-2} \mathrm{phenotypes.} \mathrm{Out} \mathrm{of} \mathrm{the} 34$ healthy controls ( $\mathrm{HbAA}), 44 \%$ had $\mathrm{Hp} 1-1$ phenotype, 38\% had Hp 2-1 phenotype and 18\% had Hp2-2 phenotype. There was a highly significant difference in the distribution of haptoglobin phenotypes among the three groups $(P=0.0001)$. The sickle cell trait $(A S)$ had high frequency of $\mathrm{Hp2}-1$. The sickle cell disease individuals (SS) had higher frequencies of Hp1-1. In conclusion, Malaria infection among the sickle cell homozygous (SS) individuals may be related to the high frequency of $\mathrm{Hp} 1-1$ and the protection of sickle cell trait (AS) against malaria infection may be due to the high frequency of haptoglobin phenotype 2-1.
\end{abstract}

\section{INTRODUCTION}

Sickle cell anemia is a haemoglobinopathy due to a single point mutation in the $\beta$-chain of human haemoglobin. The amino acid valine replaces glutamic acid in the sixth position of the $\beta$-globulin chain (Marotta et al., 1977). The homozygous inheritance of this abnormality produces, haemoglobin SS and individuals with this genotype suffer from sickle cell anemia. Subjects with the heterozygous form designated AS and are essentially healthy unless exposed to extreme conditions (Serjeant, 1988).

It has been postulated that the sickle cell mutation developed originally to protect people from dying of malaria (Luzzatto, 1981). Evidence for the partial protection of sickle cell trait individuals from Plasmodium falciparum parasitaemia came from observations based on geographical distribution, population studies and hospital based patients studies (Nagel et al., 1992). The mechanism of protection has been shown by in vitro experiments and $P$. falciparum cultures. The Plasmodium induces sickling of the erythrocytes containing $\mathrm{HbS}$ and this will lead to either its direct damage, or because the cell will be removed by the reticuloendothelial system, breaking the life cycle of the parasite (Luzzatto, 1979; and Nagel et al., 1992, Friedman 1994). Mackey and Vivarelli (1954) made two important deductions: there is the possibility that sickle cell haemoglobin may be an unsuitable intracellular environment for the growth and metabolism of the trophozoite. Alternatively parasitization of cell containing a certain proportion of sickle cell haemoglobin could lead to its in vitro sickling and phagocytosis, thus terminating the reproduction cycle. Different species of Plasmodia are able to metabolise haemoglobin efficiently and it is the source from which the parasite derives its adequate supply of the most amino acids (Howells et al., 1970). Perhaps amino acid substitutions were the wrong food for different Plasmodia. Bayoumi (1987) suggested that the selective advantage of $\mathrm{HbAS}$ individuals is due to earlier acquisition of immunity against $P$. falciparum. Other investigators have shown that individuals with sickle cell trait who have clinical malaria had lower plasma soluble IL-2 receptors and parasite counts compared to normal subjects (AbuZaid et al., 1992). However, the ultimate mechanism 
is still not fully clarified. The protective mechanism is true for the heterozygous individuals, but on the other hand, homozygous patients although the SS haemoglobin does not favour the parasite growth, usually die of malaria in tropical Africa (Onwubalili, 1983). Konotey-Ahulu, (1971), in Ghana has shown that $12.5 \%$ of these patients with HbSS had crisis precipitated by malaria. Plasmodium falciparum infection by itself is known to cause severe haemolytic anaemia (Philips et al., 1992). The wellknown fact that malaria can be extremely severe and sometimes lethal in SS homozygotes is one argument in favour of parasite removal being mediated by phagocytosis, rather than caused directly by sickling (Konotey-Ahulu, 1996). The fact that patients with sickle cell disease - as opposed to AS heterozygotes - are not malaria-resistant must always be remembered as an important point in clinical practice, quite apart from its implications in terms of protective mechanisms.

The additive effects of haemolysis with fever and vomiting, the common features of malaria will be disastrous to an early frail patient (Fleming, 1989).

\section{MATERIAL AND METHODS:}

Study design: The study was designed as hospital based case control study that included 127 children clinically diagnosed as sickle cell patients at paediatric hospital at Khartoum state following ethical considerations. Most of the cases belonged to Messeria tribe however other tribes .g. Kawahla, Gawamaa, Falata, Nuba, Rizaigat, Messeria ...etc. were included. The age group of all selected individuals was between 6 months to 17 years.

Children were classified into: HbSS group $(n=88)$, $\operatorname{HbAS}(n=39)$ and healthy group $\operatorname{HbAA}(n=34)$ using whole blood electrophoresis separation on cellulose acetate paper and then stained with ponceau $S$ according to Kohn method 1969,(Figure 1).

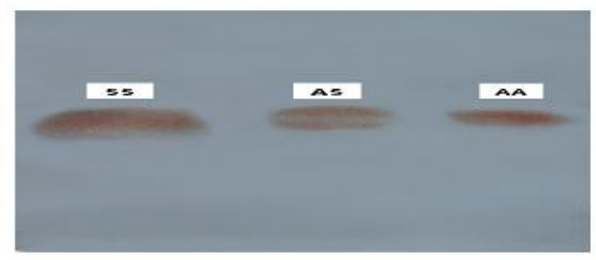

Figure 1: Cellulose acetate paper electrophoresis of blood and stained ponseau s , showing Hb types of sickle cell disease [SS], sickle cell trai and normal haemoglob in
Haptoglobin phenotyping: Haptoglobin typing were performed by polyacrylamide gel electrophoresis (Linke,1984). Plasma samples were incubated with erythrocyte hamolysate and mixed with loading buffer before application to the gel. The loading buffer was prepared by dissolving a few crystals of bromophenol blue in $40 \%$ sucrose solution. Haptoglobin complex $(\mathrm{Hp}-\mathrm{Hb})$, were separated by discontinous polyacrylamide gel electrophoresis according to Davis and Ornesten (1968). The separated gel had concentration of $4.7 \%$ polyacrylamide and the stacking gel was $2.5 \%$.

After completion of the run, the gel was stained for 10-15 minutes with benzidine stain ( $\mathrm{H}$-sigma) $200 \mathrm{mg}$ benzidine powder, $15 \mathrm{ml}$ methanol, $5 \mathrm{ml}$ glacial acetic acid, $40 \mathrm{ml} \mathrm{H} \mathrm{H}_{2} \mathrm{O}$ and $60 \mu \mathrm{l} \mathrm{H}_{2} \mathrm{O}_{2}$ ). The gel was then washed in distilled water before drying and photography.Figure 2 shows the different $\mathrm{Hp}$ phenotypes in polyacrylamide gel.

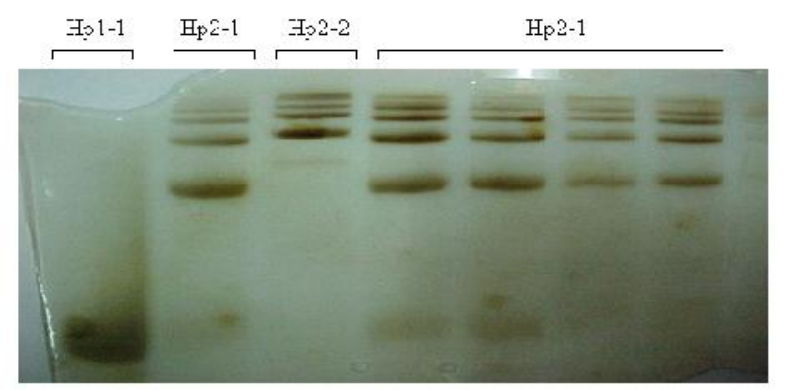

Figure 2: typ ical electrop horesis patt ern of $H$ s phenotypes 1-1,2-1 and $2-2$ on $4.7 \%$ polyacrylamice ge. electrcphresis of 13 supp.erented ser um or plasma and stained witz Benzid:ne.

Statistical analysis: Data was analyzed using SPSS program and Haptoglobin phenotype among diseased and healthy control groups was done using chisquare test.

\section{RESULTS:}

This study showed that among 127 children 88 were homozygous sickle cell haemoglobin (SS), 39 individuals sickle cell trait (AS) and 34 individuals were (AA) and were used as healthy controls. Figure 1 shows the electrophoresis separation of haemoglobin type's separation on filter paper.

Of the 88 homozygous sickle cell anaemia patients (SS), $77.3 \%$ patients had the Hp 1-1 phenotype, $22.7 \%$ had the Hp 2-1 phenotype, and none of them had $\mathrm{Hp} \mathrm{2-2} \mathrm{type.} \mathrm{Of} \mathrm{the} 39$ sickle cell trait (AS) individuals, $41 \%$ individuals had Hp1-1 phenotype, $59 \%$ had Hp2-1 phenotype and none of them had the 
Hp 2-2 phenotypes. Of the 34 healthy controls (AA), $44 \%$ had $\mathrm{Hp} 1-1$ phenotype, $38 \%$ had $\mathrm{Hp} \mathrm{2-1}$ phenotype and $18 \%$ had Hp2-2 phenotype. There was a highly significant difference in the distribution of haptoglobin phenotypes among the three groups $(\mathrm{P}=$ 0.0001) ( Table 1).

Table (1): Frequencies of different $\mathrm{Hp}$ phenotypes in patients with $\mathrm{HbSS}, \mathrm{HbAS}$ ) and healthy control HbAA individulas.

\begin{tabular}{|c|c|c|c|c|c|c|c|}
\hline \multirow[t]{2}{*}{ Group } & \multicolumn{2}{|c|}{ Hp1-1 } & \multicolumn{2}{|c|}{ Hp2-1 } & \multicolumn{2}{|c|}{ Hp2-2 } & \multirow[t]{2}{*}{ Total } \\
\hline & $\mathbf{n}$ & $\%$ & n & $\%$ & $n$ & $\%$ & \\
\hline HbSS & 68 & 77.3 & 20 & 22.7 & 0 & 0 & 88 \\
\hline HbAS & 16 & 41 & 23 & 59 & 0 & 0 & 39 \\
\hline HbAA & 15 & 44 & 13 & 38 & 6 & 18 & 34 \\
\hline
\end{tabular}

$P=0.0001$

\section{DISCUSSION}

It has been postulated that the sickle cell mutation developed originally to protect people from dying of malaria (Luzzoto, 1981). Evidence for the partial protection of sickle cell trait individuals from $P$. falciparum parasitaemia came from observations based on the geographical distribution, population studies and hospital based patient studies (Ntoumi et al., 1997). Some investigator suggested that, the protection is due to acquisition of immunity against $P$. falciparum. However, the ultimate mechanism is still not clarified. One obvious puzzling question is why sickle cell homozygous does not show the same clinical resistance to $P$. falciparum malaria as sickle cell traits individuals. Previously we found an association between the presence of high frequency of haptoglobin1-1 and susceptibility to P.falciparum malaria infection. However high frequency of Hp2-1 and Hp2-2 individuals confirmed resistance to malaria (Elagib et al., 1998, Quaye et al., 2000).

The mechanism of protection has been suggested to be due to breaking the cycle of the parasites due to early haemolysis of parasitized RBCs, (Freidman, 1978 ; Luzzotto, 1981). Bayoumi, (1987) suggested the selective advantage of $\mathrm{HbAS}$ individuals is due to earlier acquisition of immunity against $P$. falciparum. However, the ultimate mechanism is yet to be understood.

Patients with sickle-cell disease have an increased susceptibility to bacterial infections particularly to Streptococcus pneumonia, Haemophilus influenza, (Powars et al., 1983; Chudwin et al., 1985). It has been reported that patients with sickle-cell anaemia have reduced opsonic function against pneumococci (Winklstein and Drachman, 1968; Pearson, 1977). This was explained by a defective alternative complement pathway (Johnston et al., 1973 ; Wilson, 1983). Reduced opsonic function may also be related to IgG antibody deficiency against the bacterial polysacharide coat or specific IgG subclasses (Bjornson and Lobel, 1987). Reduced concentration of C3, C4 and factor B have also been reported (Wilson et al., 1983). Other investigators have not found any defect in the complement activation (Boghossian et al., 1985; Mohamed et al., 1992).

We determined the $\mathrm{Hp}$ phenotype in sickle cell diseases patients. The haptoglobin phenotype Hp1-1 frequency was high (77.3\%) among sickle cell anaemia , and this agreed with the result of Ostrowski et al.,1987, who found association of $\mathrm{Hp} 1$ and sickle cell disease. Patients with sickle cell anaemia usually die from malaria in tropical Africa, (Adeloye et al., 1971; Konotey et al.,1971; Onwubalili, 1983).

The current study suggested that protection of sickle cell trait individuals against $P$. falciparum infection might be associated with the high frequency of haptoglobin phenotype 2-1.

The role of $\mathrm{Hp}$ phenotyping in the protection and or susceptibility to malaria in sickle cell disease needs further investigations and studies should be expanded to cover the West African countries.

\section{REFERENCES}

Abu-Zaid, Y. A., Theander, T. G., Abdulhadi, N., Hviid, L., Saeed, B., Jepsen, S. Jensen, J. and Bayoumi, R (1992). Modulation of the cellular immune response during Plasmodium falciparum infections in sickled cell trait individuals. Clinical and Experimental Immunology, 88: 112-118.

Adeloye, A.,Luzzato, L.,Edington, G. M. (1971). Severe malarial infection in patient with sickle cell anemia. British Medical Journal, 1: 445.

Bayoumi, R.A. (1987). The sickle cell trait modifies the intensity and specificity of the immune response against Plasmodium falciparum malaria and leads to acquired protective immunity. Medical Hypotheses, 22: 287-298. 
Bjornson, A and Lobel, J (1987). Direct evidence that decreased serum opsonization of streptococcus pneumoneae via the alternative complement pathway in sickle cell disease is related to antibody difficiency. Journal of Clinical Investigation, 79: 388-398.

Chudwin, D. S., Korenblit, A. D., Kingzette, M., Artrip, S., Roa, S. (1985). Increased activation of the alternative complement pathway in sickle cell disease in Africa. Clinical Immunology and Immunopathology, 37:93-97.

Davis, I and Ornsten, J. (1968). Disc electrophoresis, acrylamide gel columns. In: Methods in immunology and immunochemistry, vol.2, Willimans, C.A and Chase, M.W (editor). New York: Academic Press,pp. 38-47.

Elagib, A., Kider, A., Akerstrom, B. and Elbashir, M (1998). Association of haptoglobin phenotype (1-1) with falciparum malaria in Sudan. Transactions of the Royal Society of Tropical Medicine and Hygiene, 92:309-311.

Fleming, A.F. (1989). The presentation, managment and prevention of crisis of sickled cell disease in Africa. Blood Rev, 3: 18-28

Friedman, M.J. (1978). Erythrocytic mechanism of sickled cell resistance to malaria. Proceedings of the National Academy of Science, USA, 75(4): 1994-1997.

Howells, R. E.(1970). Theory for the chloroquine resistance in rodent malaria. Nature, 228: 625-628.

Link, R.P. (1984). Typing and subtyping of haptoglobin from native serum using disc gel electrophoresis in alkaline buffer: application to routine screening. Analytical Biochemistry, 141: 55-61.

Johnston, R. B., Newman, S. L. and Struth, A. G. (1973). An abnormality of the alternate pathway of complement activation in sickle cell disease. New Journal of Infectious diseases, 136 (Suppl.): S 25-S 29.

Kohn, J (1969). Separation of haemoglobins on cellulose acetate. Journal of clinical Pathology, 22:109-111.

Konotey-Ahulu, F.I.D. (1971). Malaria and sickle cell disease. British Medical Journal, ii: 710-711

Konotey-Ahulu, F.I.D. (1996). The sickle cell disease patient. Tetteh-A'domeno Company, Watford, England (Publishers). pp. 94-96.

Luzzotto, L. (1981). Haemoglobinopathies including thalassaemia. Part 3. Sickle cell anaemia in tropical Africa. Clinic Haematology, 10(3): 757-784.

Luzzotto, L. (1979). (review), Genetics of red cells and susceptibility to malaria.Blood, 54(5): 961-976.

Mackey, J. P. and Vivarelli, I. (1954). Sickle cell anemia. British Medical Journal, 1: 276.
Marotta, C. A., Wilson, J. T., Forget, B. C., Wissman, S. M. (1977). Human $\beta$-globin messenger RNA. III. Nucleotide sequences derived from complementary DNA. Journal of Bilogical Chemistry, 252: 5040-5051.

Mohamed, A.O., Nilson, U.R., Omer, M.I. and Ronquist, G. (1992). Lack of evidence for altered complement and immunoglobulin levels in patients with sickle cell anemia. Scandnavian Journal of Clinical Laboratory investigations, 52: 313-316.

Nagel, R., and Fleming, A. (1992). Genetic epidemiology of the $\beta^{s}$ gene. Bailliere's Clinical Haematology, 5(2): 331-365.

Natta C. L., Outschoorn I. M. (1984). IgG2 deficiency in sickle cell anaemia. Scondinavian journal of Haematology, 33: 129-134.

Ntoumi, F., Merceraeau-Puijalon, O., Ossari, S., Luty, A., Reltien, J., Georges, A. and Millet, P. (1997). Plasmodium falciparum: Sickle-Cell Trait is associated with higher prevalence of multiple infections in Gabonese Children with asymptomatic infections. Experimental Parasitology, 87: 39-46.

Onwubalili, J.K. (1983). Sickle cell disease and infection. Journal of Infections, 7: 2- 20.

Ostrowski, R., Travis, J., Talley, E. (1987). The association of $\mathrm{Hp} 1$ and sickleCell disease. Human Heredity, 37: 193-195.

Pearson, H. A. (1977). Sickle cell and severe infections due to encapsulated bacteria. England Journal of Medicine, 288(16): 803-808.

Powars, D, Overturf, G., Turner, E. (1983). Is there an increased risk of Haemophilus influenzae, Septicemia in children with sickle cell anemia?. Pediatrics, 71(6): 927-931.

Phillips, R.E., Pasvol, G. (1992). Anaemia of Plasmodium falciparum malaria. Bailliere's Clinical Haematology, 5(3): 315-330.

Quaye, I., Ekuban, F., Goka, B., Adabayeri, V., Kurtzhals, J., Gyan, B., Ankrah, N., Hviid, L., Akanmori, B. (2000). Haptoglobin 1-1 is associated with susceptibility to severe Plasmodium falciparum malaria. Transaction of the Royal Society of Tropical Medicine and Hygiene, 94(2): 216-219.

Serjeant, G. R. (1988). Sickle cell disease. Oxford: Oxford Medical Publications.

Winkelstein, J. A., Drachman, R. H. (1968). Deficiency of pneumococcal serum opsonizing activity in Sickle cell disease. New England Journal of Medicine, 279(9): 459-466.

Wilson, W. A. (1983). Nature of complement deficiency in sickle cell disease. Arch. Dis. Child, 58(3): 235-237. 